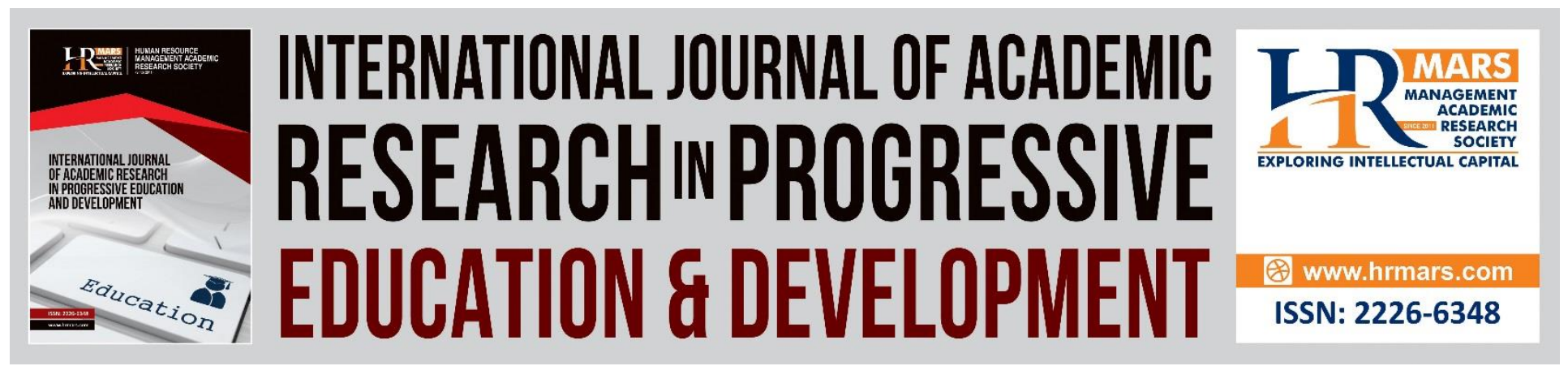

\title{
Content Assessment on Pendidikan Islam Subject in Creating Learning Application for Hearing Impaired Students
}

Abdul Rahim Razalli, Mohd Hanafi Mohd Yasin, Nordin Mamat, Modi Lakulu, Abdul Talib Mohamed Hashim \& Azli Ariffin

To Link this Article: http://dx.doi.org/10.6007/IJARPED/v10-i1/9006 DOI:10.6007/IJARPED/v10-i1/9006

Received: 18 December 2020, Revised: 21 January 2021, Accepted: 06 February 2021

Published Online: 26 February 2021

In-Text Citation: (Razalli et al., 2021)

To Cite this Article: Razalli, A. R., Yasin, M. H. M., Mamat, N., Lakulu, M., Hashim, A. T. M., \& Ariffin, A. (2021). Content Assessment on Pendidikan Islam Subject in Creating Learning Application for Hearing Impaired Students. International Journal of Academic Research in Progressive Education and Development, 10(1), 562574.

Copyright: (C) 2021 The Author(s)

Published by Human Resource Management Academic Research Society (www.hrmars.com)

This article is published under the Creative Commons Attribution (CC BY 4.0) license. Anyone may reproduce, distribute, translate and create derivative works of this article (for both commercial and non-commercial purposes), subject to full attribution to the original publication and authors. The full terms of this license may be seen at: http://creativecommons.org/licences/by/4.0/legalcode

Vol. 10(1) 2021, Pg. 562 - 574

http://hrmars.com/index.php/pages/detail/IJARPED

JOURNAL HOMEPAGE

Full Terms \& Conditions of access and use can be found at http://hrmars.com/index.php/pages/detail/publication-ethics 


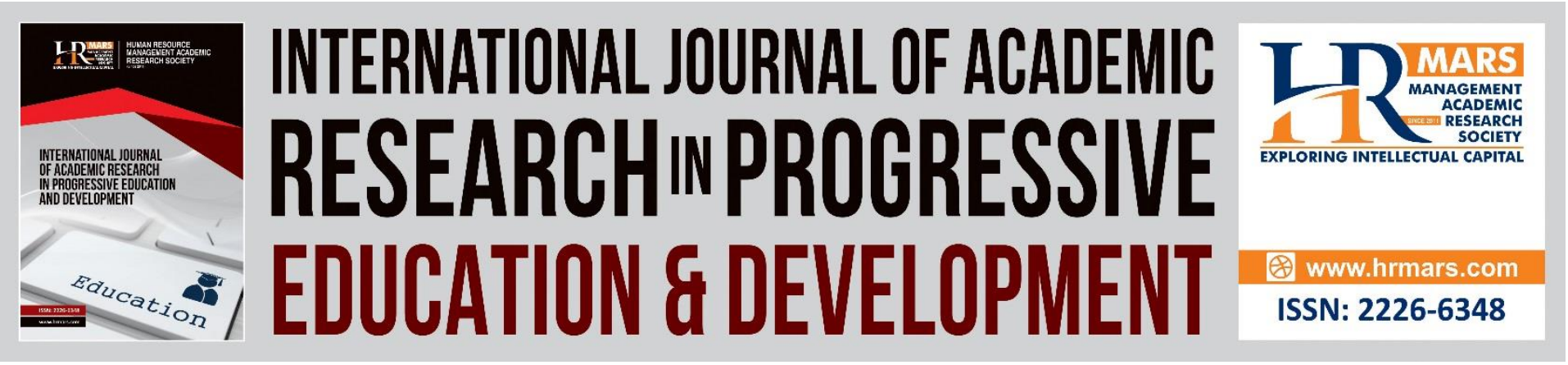

\title{
Content Assessment on Pendidikan Islam Subject in Creating Learning Application for Hearing Impaired Students
}

\author{
Abdul Rahim Razalli, Mohd Hanafi Mohd Yasin, Nordin Mamat, \\ Modi Lakulu, Abdul Talib Mohamed Hashim \& Azli Ariffin. \\ Universiti Pendidikan Sultan Idris
}

\begin{abstract}
This study evaluates the content of Pendidikan Islam (Islamic Education) subject in creating a software application for students with hearing problems. For this purpose, survey methods are used to determine the content and design of the software developed. The study findings show that i'badah (worship) recorded the highest mean of 4.35 and 0.534 compared to Aqidah, Akhlaq, Sirah, Al-Quran and Hadith. The topic of Salah (prayer) which comes under I'badah category, recorded the highest mean with a value of 4.57 and s.d $=0.486$ compared to Wudhu' (ablution), Istinja' (removing impurity), Ghusl (full ablution), the Concept of Purification, and the Concept of I'badah and Categories of Hukm Shari'e (rule of Islamic law). The overall study found that the mean of agreement is at a high level with 3.5; $\mathrm{s.d}=0.407$ or 76.7 percent agreed with the design features namely text, graphics, animation, sound, font, interactive, screen navigation, color and flexibility hence they are given priority in creating Islamic Education software application for topic of Salah under I'badah category. Realizing the application on solah is very much needed by hearing impaired students, thus its features should be technology friendly for persons with disabilities (PWD) to ensure effective and organized information sharing on aspects of $i$ 'badah.

Keyword: Assessment, Development, Application, Hearing Impairment, Islamic Education.
\end{abstract}

\section{Introduction}

In Malaysia, the government provides educational opportunities to PWD as underlined by the Accessibility and Education Policy through Persons with Disabilities Act 2008). This policy encourages provision of facilities and access for individuals with special needs to Information and Communication Technology (ICT) while increasing their access to education at all levels. This policy is in line with the National Education Philosophy (NEP) which is equal rights on education for every Malaysia citizens, meaning those with healthy body and mind as well as individuals with special needs. The policy outlined by the government is in accordance with Reed statement (2004) who addressed that assistive technology plays a pivotal role in helping students with special needs, particularly in the teaching and learning process. The technology further helps to 
minimize educational disparities and it seems to be a more focused and effective approach. Moreover, the technology helps to enhance, maintain or improve the functional capacity of special education students (Individual with Disabilities Education Act or IDEA, 1997).

The development of ICT is seen to be growing rapidly. Zaffwan et. al (2013) explains the development of ICT as well as the use of computers that brings great implications in various areas of human life including education. The ICT development promises great potential in education, by changing the learning style, methods of information searching, ways to adapt to information and many more. The Special Education Integration Program (SIEP) is also no exception to the ICT development that bring many benefits to the teaching and facilitation process in schools with Special Education Integration Classes. Mobile application technology or mobile apps can be integrated in various fields especially in Islamic Education subject. Hakimi, et.al. (2014) explains that the subject should keep its pace along with the progress of science and technology. Hence, study areas namely Al-Quran, Hadith, A'qidah, I'badah, Sirah and Akhlaq contained in The Standards-Based Curriculum and Assessment Document (DSKP) have been empowered through the use of mobile applications to impart Islamic knowledge in accordance with changes of times.

\section{Problem Statement}

Mobile applications or mobile apps are programs that are loaded into mobile devices. They can be used anytime and anywhere (Islam, et.al, 2010). Mobile applications consist of software or sets of program that run on mobile devices and perform specific tasks for users. Smartphone applications are created by individuals, businesses, government agencies, the military, educational institutions and any other organization for purpose of entertainment, problem solving and meeting daily needs. Simple, user-friendly, and inexpensive mobile app features allow most mobile phone users to download such application. Although there are so many applications being developed recently, however Nawi \& Hamzah (2013) observed that smartphone applications for religious purposes, Islam in particular, is still lacking in numbers compared to other applications. Islamic-based applications on mobile phones with the introduction of Ilkone 1800 were the first Islamic-characterized mobile devices developed (Wyche, Caine et. al, 2008).

In another research by Nawi \& Hamzah (2013), it was found that the use of mobile applications in education is still at early stages in Malaysia. While Ismail et. al. (2016) stated that mobile application technology or mobile apps can be integrated in various fields of knowledge, especially Islamic knowledge. This application is very helpful for users at all ages who are seeking for religious information. The study results found that Islamic applications are still few in numbers. Nevertheless, most Islamic mobile apps are constantly updated by app developers (Ismail et. al, 2016). Therefore, research on development of Islamic smartphone applications needs to be pursued continuously. The use of blogs, social media, websites, applications on mobile phones such as WhatsApp and text messaging (SMS) are some examples of technological facility being manipulated in the world of technology. In fact, there is abundance of applications that are yet to be explored by researchers on their effectiveness to improve the overall quality of teaching and facilitation. Therefore, it is very important for educators to explore the 
probabilities and uses of appropriate technology applications within education setting (Kaminski, et.al, 2009). Changes in the role of teaching and learning are inevitable with the introduction of multimedia technology in education. Moreover, information exchanged in the digital mode as well as education curriculum that evolved through combination of multimedia and interactive elements are intended to create better teaching and learning (T\&L) environment for both students and teachers. Integration of multimedia in the classroom has become a global trend, with strong support from the Malaysian government to adopt technology in the classroom (Sahir, 2011). The study of Razalli et.al (2015) found that i'badah-based applications are still few in numbers. The data is presented from the table below.

TABLE I Islamic Education Content in Software Applications

\begin{tabular}{lll}
\hline No. & Application Search Theme & Total Number of Applications \\
\hline 1. & Fardh' Prayer Guide & 65 \\
2. & Recitations in Fardh' Prayer & 30 \\
3. & Fardh' Prayer Guide in Malay Language & 16 \\
4. & Fardh Prayer Guide for Deaf Persons & - \\
5. & Recitations in Fardh' Prayer for Deaf Persons & - \\
6. & Fardh' prayers in Malay Language for Deaf Persons & - \\
\hline
\end{tabular}

Deaf students refer to individuals with severe impairment on auditory and speech senses. However, they are able to see and have strong memory capability like any mainstream students (Razalli et al, 2018). It is observed that teaching materials commonly used by Islamic Education teachers are mostly material designed for mainstream students containing lengthy description text, limited visual illustration on prayer movements, and absence of sign language interpreters in particular Kod Tangan Bahasa Melayu (KTBM) known as the Manually Coded Malay (MCM). According to a study conducted by Ronizam, et al (2016), despite the development of latest technology such as mobile application technology or mobile apps that can be integrated in various academic fields, especially on Islamic knowledge, Islamic application materials produced, however, are still few in numbers.

\section{Objectives}

- To assess the content of Islamic Education subject and the content designed on mobile application software.

\section{Literature Review}

Most trends now opt for a more modern lifestyle with the use of sophisticated computing and mobile application devices. Various computer applications are being developed for use in smartphones. Technology in developing application software nowadays covers a wide range of fields. With the use of technology, this application software makes it more effective and capable to solve problems that exist (Pattison \& Stedmon, 2006). Mobile applications or 'mobile apps' is a program designed for smartphones to facilitate users in daily affairs (Ismail, et. al, 2016). 
Ismail et.al (2016) in their study addressed that mobile application technology or mobile apps can be integrated in various fields of knowledge, especially Islamic knowledge. This application is very helpful for users of all ages who wanted to learn about Islam. The study results found that earlier literary works on Islamic applications is scarce in numbers. Mamat et.al, (2020) has mentioned the general need for technologies to support lifelong learning. Mamat et. al (2020), presented some advantages that can also be used to determine the practice in $\mathrm{m}$ learning. m-Learning is suitable for daily communication needs of deaf students and teaching with technology support as an initial exposure to ICT. Moreover, it also helps deaf students to use technology and communicate using mobile devices in real life. In fact, they will gain new experience in communication.

A good and genuine education is principally based on the concept of monotheism. To explain, a noble human personality can be developed through monotheism and harmonious combination between knowledge, kindness, soul and pious deeds (Haron \& Sobri, 1988). Therefore, Islamic Education should be positioned as the foundation that underlies the progress of science and technology (Ahmad, 2014). Islam has put education at a high position and its importance is very much emphasized in the first verse of the Qur'an, namely surah al-'Alaq, verses 1-5. In response to this call, the subject of Islamic Education has been incorporated into the national education system and has become a compulsory subject for all Muslim students (Ahmad, 2014). The Islamic Education curriculum that is introduced in Malaysian education system is purposefully to foster a true Muslim identity that is in accordance with Islamic law. It is a subject that must belearned by every Muslim student, whether they are at the primary, secondary or tertiary level. The Islamic Education curriculum, covers A'qidah, Shari'ah, I'badah and Sirah that help to develop good Muslim character among students if they really embraced the teachings in real life.

With reference to the Standards-Based Curriculum and Assessment Document (DSKP) for Islamic Education Form 1, the topic of Solah has been refined and improved by the relevant parties. Based on the DSKP, students need to study the topic for 3 years, beginning from Form 1 until Form 3 (MOE, 2016). Learning theory and learning strategies should be considered to develop a good and quality ICT-assisted application software. It is also to achieve teaching goals and ensure students to maintain their focus on the topics contained in the application software. The learning process in a classroom setting can be fully received by Special Education students with Hearing Impaired if learning theories and strategies are applied correctly. The application software will achieve its effectiveness if the developer takes into account the use of theory and learning strategies. An effective teaching will occur if the design also considers the basics found in the learning theory. One of the theories used in the software is Tariq (2020) who explains the behavioral theory approach. Each stimulus elicits responses and learning occurs resulted from relation to stimuli and responses. A stimulus related to another stimulus will bring about learning known as habituation. For example, prayer application software can engage students to learn more about solah since it can be easily accessed using smartphone. The first stimulus is computer and the second stimulus is an interesting way of teaching. Since the relationship between the two stimuli is positive, therefore the response will eventually turns positive. 
Vol. 10, No. 1, 2021, E-ISSN: 2226-6348 @ 2021 HRMARS

\section{Research Methodology}

This study is carried out using survey method with a set of questionnaires as an instrument for data collection. The data is collected through the use of questionnaire containing 72 items with five options using 5-point Likert scale of 1 (Strongly Disagree), 2 (Disagree), 3 (Not Sure), 4 (Agree) and 5 (Strongly Agree). The items represent six areas under study namely Al-Quran, Hadith, A'qidah, I'badah, Sirah and Akhlaq. As for data on the content design of mobile application software contains 36 items. A total of 30 teachers were involved in the special education program with hearing impairment selected through sampling purpose technique. Data were then analyzed descriptively using mean and percentage.

\section{Findings}

The study findings showed the priority of content in Islamic Education subject for the mobile application that involve six important areas namely Al-Quran, Hadith, A'qidah, I'badah, Sirah and Akhlaq. The overall respondents agreed to the development of mobile applications for deaf students. I'badah recorded the highest agreement with a mean of 4.35 ; s.d $=0.5341$ or 95.02 percent, followed by A'qidah with a mean of 3.84; s.d $=0.5075$ or 85.53 percent, Sirah with a mean of 3.80; s.d $=0.5325$ or 79.18 percent, Al-Quran with a mean of 3.76; $\mathrm{s} . \mathrm{d}=0.5349$ or 72.50 percent and Hadith with a mean of 3.74; s.d $=0.5341$ or 72.49 percent.

TABLE II Priorities of content in Islamic Education

\begin{tabular}{|l|l|c|c|c|}
\hline No. & \multicolumn{1}{|c|}{ Content } & Mean & $\begin{array}{c}\text { Standard } \\
\text { Deviation }\end{array}$ & Percentage of Agreement \\
\hline 1. & Al-Quran & 3.76 & 0.5349 & $72.50 \%$ \\
\hline 2. & Hadith & 3.74 & 0.5341 & $72.49 \%$ \\
\hline 3. & A'qidah & 3.86 & 0.5075 & $85.53 \%$ \\
\hline 4. & I'badah & 4.35 & 0.5341 & $95.02 \%$ \\
\hline 5. & Sirah & 3.80 & 0.5325 & $79.18 \%$ \\
\hline 6. & Akhlaq & 3.85 & 0.5495 & $74.18 \%$ \\
\hline
\end{tabular}

The finding analysis shows priority of topics in I'badah that is based on seven main topics. They are; the Concept of I'badah and Categories of Hukm Shar'ie, the Concept of Purity, the Types and Ways of Purification, Istinja', Wudhu', Ghusl and Solah contained in the Standard Content of Islamic Education Subject. The findings show that Solah is given priority in developing mobile applications for deaf students with a high mean percentage of agreement of 4.57 ; s.d $=0.486$ or 99.9 percent, followed by Wudhu' with a mean of 3.97; s.d $=0.550$ or 85.0 percent, Istinja' with 3.96; s.d $=0.547$ or 82.7 percent, Types and Method of Purification with a mean value of 3.95; $\mathrm{s} . \mathrm{d}=0.574$. There are three topics with mean recorded, namely the Concept of I'badah and the Categories of Hukm Shar'ie, the Concept of Purification and Ghusl with the value of 3.94. 
INTERNATIONAL JOURNAL OF ACADEMIC RESEARCH IN PROGRESSIVE EDUCATION AND DEVELOPMENT

Vol. 10, No. 1, 2021, E-ISSN: 2226-6348 @ 2021 HRMARS

TABLE III Topics on I'badah

\begin{tabular}{|l|l|r|r|c|}
\hline No. & \multicolumn{1}{|c|}{ Topics on l'badah } & Mean & \multicolumn{1}{|c|}{$\begin{array}{c}\text { Standard } \\
\text { Deviation }\end{array}$} & $\begin{array}{c}\text { Percentage of } \\
\text { Agreement }\end{array}$ \\
\hline 1. & $\begin{array}{l}\text { The Concept of I'badah and } \\
\text { Categories of Hukm Shar'ie }\end{array}$ & 3.94 & 0.473 & $82.80 \%$ \\
\hline 2. & Purification Concept & 3.94 & 0.534 & $81.67 \%$ \\
\hline 3. & Purification Types and Method & 3.95 & 0.574 & $81.12 \%$ \\
\hline 4. & Istinja' & 3.96 & 0.547 & $82.75 \%$ \\
\hline 5. & Wudhu' (Ablution) & 3.97 & 0.550 & $85.00 \%$ \\
\hline 6. & Ghusl (Full ablution) & 3.94 & 0.525 & $82.77 \%$ \\
\hline 7. & Solah (Prayer) & 4.57 & 0.486 & $99.95 \%$ \\
\hline
\end{tabular}

As for the analysis on content design of mobile application software, the findings revealed that

\begin{tabular}{|c|c|c|c|c|c|c|c|c|}
\hline \multirow{2}{*}{$\begin{array}{c}\text { NO } \\
\text {. }\end{array}$} & \multirow{2}{*}{ STATEMENT } & \multicolumn{5}{|c|}{$\begin{array}{l}\text { Scale and Percentage of } \\
\text { Agreement (\%) }\end{array}$} & \multirow[t]{2}{*}{ Mean } & \multirow[t]{2}{*}{ SD } \\
\hline & & $\begin{array}{c}1 \\
\text { SD }\end{array}$ & $\begin{array}{l}2 \\
D\end{array}$ & $\begin{array}{c}3 \\
\text { NS }\end{array}$ & $\begin{array}{l}4 \\
A\end{array}$ & $\begin{array}{c}5 \\
S A\end{array}$ & & \\
\hline 1. & $\begin{array}{l}\text { There is combination of text, images, } \\
\text { graphics, animation and sound in this } \\
\text { application software. }\end{array}$ & & & $\begin{array}{c}(5) \\
16.7\end{array}$ & $\begin{array}{l}(24) \\
80.0\end{array}$ & $\begin{array}{l}(1) \\
3.3\end{array}$ & 3.86 & 0.434 \\
\hline 2. & $\begin{array}{l}\text { The combination of text, images, } \\
\text { graphics, animation and sound in this } \\
\text { application software simplifies the } \\
\text { information delivery process. }\end{array}$ & & & $\begin{array}{c}(9) \\
30.0\end{array}$ & & & 3.70 & 0.466 \\
\hline 3. & $\begin{array}{l}\text { Multimedia elements such as text, } \\
\text { images, graphics, animation and sound } \\
\text { help the learning environment more } \\
\text { enjoyable. }\end{array}$ & & & $\begin{array}{l}\text { (6) } \\
20\end{array}$ & $\begin{array}{l}\text { (22) } \\
73.3\end{array}$ & $\begin{array}{l}\text { (2) } \\
6.7\end{array}$ & 3.86 & 0.507 \\
\hline 4. & $\begin{array}{l}\text { Images, graphics, color text and } \\
\text { animations featured in this application } \\
\text { software are appealing to students. }\end{array}$ & & & $\begin{array}{c}(5) \\
16.7\end{array}$ & $\begin{array}{l}\text { (23) } \\
76.7\end{array}$ & $\begin{array}{l}\text { (2) } \\
6.7\end{array}$ & 3.90 & 0.480 \\
\hline 5. & $\begin{array}{l}\text { The link buttons available in this } \\
\text { application software helps the user to } \\
\text { control the software easily during } \\
\text { learning. }\end{array}$ & & & $\begin{array}{l}(10) \\
33.3\end{array}$ & $\begin{array}{l}(19) \\
63.3\end{array}$ & $\begin{array}{l}\text { (1) } \\
3.3\end{array}$ & 3.70 & 0.534 \\
\hline 6. & $\begin{array}{l}\text { The screen display in this application } \\
\text { software is always consistent. }\end{array}$ & & & $\begin{array}{l}(6) \\
20\end{array}$ & $\begin{array}{l}(24) \\
80\end{array}$ & & 3.80 & 0.406 \\
\hline 7. & $\begin{array}{l}\text { The interactive link buttons allow users } \\
\text { to easily explore the Prayer Mobile } \\
\text { Application Software. }\end{array}$ & & & $\begin{array}{c}(12) \\
40\end{array}$ & $\begin{array}{c}(18) \\
60\end{array}$ & & 3.60 & 0.498 \\
\hline 8. & $\begin{array}{l}\text { Navigation available on the screen } \\
\text { facilitates access to information. }\end{array}$ & & & $\begin{array}{l}(6) \\
20\end{array}$ & $\begin{array}{l}(24) \\
80\end{array}$ & & 3.80 & 0.406 \\
\hline
\end{tabular}


INTERNATIONAL JOURNAL OF ACADEMIC RESEARCH IN PROGRESSIVE EDUCATION AND DEVELOPMENT

Vol. 10, No. 1, 2021, E-ISSN: 2226-6348 @ 2021 HRMARS

\begin{tabular}{|c|c|c|c|c|c|c|}
\hline 9. & $\begin{array}{l}\text { The design on Mobile Prayer Application } \\
\text { Software display screen is appealing and } \\
\text { suitable for hearing Disabled Students } \\
\text { (HDS). }\end{array}$ & $\begin{array}{c}(7) \\
23.3\end{array}$ & $\begin{array}{l}(14) \\
46.7\end{array}$ & $\begin{array}{l}(9) \\
30\end{array}$ & 4.06 & 0.739 \\
\hline 10. & $\begin{array}{l}\text { This application software uses fonts that } \\
\text { are clear and easy to read. }\end{array}$ & $\begin{array}{l}(6) \\
20\end{array}$ & $\begin{array}{l}(23) \\
76.7\end{array}$ & $\begin{array}{l}(1) \\
3.3\end{array}$ & 3.83 & 0.461 \\
\hline 11. & $\begin{array}{l}\text { The graphics and images used in this } \\
\text { application software attract students } \\
\text { with special hearing needs to learn. }\end{array}$ & $\begin{array}{c}(15) \\
50\end{array}$ & $\begin{array}{l}(14) \\
46.7\end{array}$ & $\begin{array}{l}(1) \\
3.3\end{array}$ & 3.53 & 0.571 \\
\hline 12. & $\begin{array}{l}\text { The colors used in this application } \\
\text { software are suitable for students with } \\
\text { special hearing needs. }\end{array}$ & $\begin{array}{c}(8) \\
26.7\end{array}$ & $\begin{array}{l}(22) \\
73.7\end{array}$ & & 3.73 & 0.449 \\
\hline 13. & $\begin{array}{l}\text { The use of video on Manually Coded } \\
\text { Malay (MCM) on every display } \\
\text { application software that makes teaching } \\
\text { and learning a fun process. }\end{array}$ & $\begin{array}{l}(6) \\
20\end{array}$ & $\begin{array}{c}(24) \\
80\end{array}$ & & 3.80 & 0.406 \\
\hline 14. & $\begin{array}{l}\text { This software is flexible, meaning that } \\
\text { teachers may choose any teaching } \\
\text { display that is suitable for students to } \\
\text { learn. }\end{array}$ & $\begin{array}{l}(6) \\
20\end{array}$ & $\begin{array}{c}(24) \\
80\end{array}$ & & 3.80 & 0.406 \\
\hline 15. & $\begin{array}{l}\text { The design on the application software } \\
\text { screen display is interesting and } \\
\text { effective. }\end{array}$ & $\begin{array}{c}(4) \\
13.3\end{array}$ & $\begin{array}{l}(19) \\
63.3\end{array}$ & $\begin{array}{c}(7) \\
23 . \\
3\end{array}$ & 4.10 & 0.607 \\
\hline 16. & $\begin{array}{l}\text { Suitable font size and type used in this } \\
\text { application software. }\end{array}$ & $\begin{array}{l}(2) \\
6.7\end{array}$ & $\begin{array}{l}(14) \\
46.7\end{array}$ & $\begin{array}{l}(14 \\
14 \\
7\end{array}$ & 4.40 & 0.621 \\
\hline 17. & $\begin{array}{l}\text { The text arrangement in this application } \\
\text { software is neat, systematic and not } \\
\text { overloaded. }\end{array}$ & $\begin{array}{l}(1) \\
3.3\end{array}$ & $\begin{array}{l}(17) \\
56.7\end{array}$ & $\begin{array}{c}(12 \\
40\end{array}$ & 4.36 & 0.556 \\
\hline 18. & $\begin{array}{l}\text { The text color used in this application } \\
\text { software is suitable for teaching at } \\
\text { preschool level. }\end{array}$ & $\begin{array}{l}(6) \\
20\end{array}$ & $\begin{array}{c}(24) \\
80\end{array}$ & & 3.80 & 0.406 \\
\hline 19. & $\begin{array}{l}\text { The translator video in this software } \\
\text { helps students with special hearing } \\
\text { needs to understand the obligatory } \\
\text { prayer procedure. }\end{array}$ & $\begin{array}{l}(6) \\
20\end{array}$ & $\begin{array}{c}(24) \\
80\end{array}$ & & 3.80 & 0.406 \\
\hline 20. & $\begin{array}{l}\text { Smooth screen switching from one } \\
\text { screen to another. }\end{array}$ & $\begin{array}{l}\text { (9) } \\
30\end{array}$ & $\begin{array}{l}(17) \\
56.7\end{array}$ & $\begin{array}{c}(4) \\
13 . \\
3\end{array}$ & 3.83 & 0.647 \\
\hline 21. & $\begin{array}{l}\text { This application software is flexible, } \\
\text { meaning that it links to other related } \\
\text { areas as well. }\end{array}$ & $\begin{array}{c}(7) \\
23.3\end{array}$ & $\begin{array}{l}(23) \\
76.7\end{array}$ & & 3.76 & 0.430 \\
\hline
\end{tabular}


Vol. 10, No. 1, 2021, E-ISSN: 2226-6348 @ 2021 HRMARS

\begin{tabular}{|l|l|l|l|c|c|c|c|c|}
\hline 22. & $\begin{array}{l}\text { Students with special hearing needs are } \\
\text { not loss while exploring each module in } \\
\text { this application software. }\end{array}$ & & $\begin{array}{c}(7) \\
23.3\end{array}$ & $\begin{array}{c}(21) \\
70\end{array}$ & $\begin{array}{c}(2) \\
6.7\end{array}$ & 3.83 & 0.530 \\
\hline & & & 22.8 & 67.8 & 9.4 & 3.85 & 0.497 \\
\hline
\end{tabular}

The finding analysis showed the content design with font size and type has the highest mean of 4.40 ; s.d $=0.621$ or 93.3 percent followed by the systematic text arrangement features with a mean of 4.36; s.d $=0.556$ or 96.7 percent. Overall, the mean agreement is at a high level of 3.5; s.d $=0.407$ or 76.7 percent agrees with design features such as text, graphics, animation, sound, font, interactive, screen navigation, color and flexibility are given priority in creating educational application design for Islamic Education particularly prayer topic under I'badah category.

\section{Discussion}

The study indicates that I'badah found to be the main topic for Islamic Education subject compared to topics of Al-Quran, Hadith, Aqidah, Akhlaq and Sirah. All of the topics are in fact areas covered in the Islamic Education Curriculum that help to foster good Muslim personality among students who really embraced the teachings (Yusof, 2006). The priority of $i$ 'badah in the design of this mobile application is supported by the study of Wyche et. al., (2008) who explained that it is an Islamic application on mobile phones with Ilkone 1800 introduced in 2004 and it is the first Islamic mobile device Islamic application that provide the Qibla direction, dua' selections, complete hadith database, dua' for 'umrah and halal food guidelines (Bunt, 2010). Additionally, there are applications that provide Hajj mobile dictionary supported with pictures and illustrations (Zeki, 2012). I'badah is also given priority because according to Khairuldin and Mohammad (2013), the Philosophy of Education according to the Al-Quran has discussed the importance of $i^{\prime}$ badah to proof the tawheedic concept on the oneness of Allah SWT. He further explained that the meaning of i'badah not only confined to prayer, fasting and zakat but also include any good deeds based on the Shari'a law. The Islamic Education Curriculum for students with hearing impairments follows the same curriculum likewise the mainstream students. Moreover, i'badah is positioned as the basic components of U'lum Shari'yah (Ministry of Education Malaysia, 2012). The Islamic Education (KBSM) subject includes three major areas, namely Tilawah al-Quran \& Hadith, Ulum Shar'iyah and Adab based on Islamic Morality. I'badah is one of the learning areas emphasized by teachers, especially area related to performance of prayers as mentioned by Johari et.al, (2016). The teaching of prayer as an I'badah aims to educate students on performing prayer obligation the right way.

The study findings further show Solah as a topic with priority compared to Concept of I'badah and Categories of hukm Shari'e, Concept of Purity, Types and ways of Purification, Istinja', Wudhu' and Ghusl. Realizing the importance of such obligations, the Ministry of Education Malaysia (MOE) has introduced the Basics of Fardh' A'in (PAFA) in 1995 to be implemented in secondary schools under MOE. The practice of solah is one of the components found in the PAFA curriculum as a complement to one of the two additional hours for Islamic Education subject. It is a special practical program to train students in performing prayers. The findings are also 
supported by Siwok et al (2018), who observed the level of prayer practice and its relationship with student morals. Moreover, there is a relation between the practice of solah with the personality of students. The results further presents the practical elements of solah that have been widely exposed to students in their teaching and learning process. Having said that, Siwok (2016) in her study shows that respondents know and understand the importance of prayer. Nonetheless, their practical in performing prayers still remains at unsatisfactory level. Solah is regarded as I'badah qawliyyah jismiyyah which is a combination of prayer between recitation of words and body movements. Solah is performed with body movements along with particular recitations. The perfection on combination of movement and recitation in solah is the essence of all i'badah obligations. While Salleh (2004) emphasized that solah is one of the most important i'badah that is obligatory upon Muslims. Solah is an i'badah bestowed with special privileges and honour. The overall study findings are similar to the study of Salman et al, (2014) who observed that the presentation process in application software can encourage response of students to use it continuously not only that, features contained in the software may create an interesting learning setting, for instance the use of multimedia elements or certain icons that function to provide information and assistance. On top of that, such features can guide the users on specific things needed while using it. Interactive application design findings further supports the study of Alessi and Trollip (1991) who claimed that mobile application software that is created to meet the needs of interactive learning will have two-way features as well as hypertext and hyperlink and also virtual reality parallel to learning constructivism. Through the use of this application software, learning not only takes place in the classroom but also occurs outside the classroom boundaries also globally if they are connected to the internet. With this application, one-way information transformation turns into two-way (non-linear) compared to conventional learning methods. Learning strategies are also known as learning methods that apply to how students respond to application software in exploring the learning process (Mamat et, al., 2020). This application software is developed using several learning strategies to ensure effectiveness of delivery and to gain maximum input in their learning process.

Meanwhile, Mukti (2000) agreed that human learning and understanding can be enhanced through interactive learning environment. ICT application software helps the student to improve their understanding and mastering solah recitations as well as giving them confidence to perform their prayer obligation. Also supported by Miswan \& Adnan (2015), the advantages of multimedia technology and multi-touch screens are the key features that will arouse interest of the students to explore the application. Having said that, most applications will commonly face either one of this two problems: Content that tends to display graphical and interactive features over educational materials, or application that is overloaded with educational materials but presented in a stereotypical and boring manner. According to Chung and Shin (2010), smartphone applications developed by individuals, businesses, government agencies, military, educational institutions and any other organization are generally meant for entertainment, problem solving and meeting daily needs. There are some earlier works taken as reference in developing the system. For the purpose of this study, it is important for researchers to be knowledgeable enough in creating a system for any application software. While Vázquez-Cano et.al (2020) in their study also identified the applications chosen by the students to share 
information and factors that drive their selection of such applications. In another study by Ismail et. al. (2016) stated that mobile application technology or mobile apps can be integrated in various fields of knowledge including Islamic knowledge. Hence, this application is a useful information sharing tool suitable for users at all ages who want to learn more about religion. The study results found that literary works on Islamic applications is very few in numbers. Even so, most Islamic mobile apps are constantly updated by app developers (Ismail et. al., 2016). Therefore, research on the development of Islamic smartphone applications needs to be done continuously. According to Sidek et al (2014), this application is a helpful learning tool for deaf students in making notes and organizing their work in school. Additionally, this application is also designed with voice recording feature to record the lessons delivered and replay the recordings. This application is very user-friendly to PWD owing to its recording feature that is convertible to written notes.

\section{Conclusion}

On a final note, the development of content-based mobile applications in Islamic Education subject is very much needed by hearing impaired and deaf students for them to learn religious knowledge both in theory and practice. Hence, the application design that is PWD-friendly will engage more users at all levels to learn about solah in an effective and systematic manner.

Implication from this study showed that the application on solah is very much needed by hearing impaired students, thus its features should be technology friendly for persons with disabilities (PWD) to ensure effective and organized information sharing on aspects of $i$ 'badah. In the context of the Special Education Integration Program (SIEP), the ICT development that brings many benefits to the teaching and facilitation process in schools with Special Education Integration Classes. Mobile application technology or mobile apps can be integrated in various fields especially in Islamic Education subject. From the perspectives of theory, Islamic Education should be positioned as the foundation that underlies the progress of science and technology. As mentioned in the theory a good and genuine education is principally based on the concept of monotheism. A noble human personality can be developed through monotheism and harmonious combination between knowledge, kindness, soul and pious deeds.

\section{Acknowledgement}

This research was completed with the support from Fundamental Research Grants Scheme (FRGS/1/2018/SSI09/UPSI/02/6) provided by the Ministry of Education of Malaysia. The Authors would like to extend their gratitude to Universiti Pendidikan Sultan Idris (UPSI) for their assistance in managing the grants.

\section{Corresponding Author}

Associate Prof. Dr. Nordin Mamat

Department of Early Childhood Education, Faculty of Human Development, Universiti

Pendidikan Sultan Idris, Perak Malaysia

Email: nordin@fpm.upsi.edu.my 
INTERNATIONAL JOURNAL OF ACADEMIC RESEARCH IN PROGRESSIVE EDUCATION AND

DEVELOPMENT

Vol. 10, No. 1, 2021, E-ISSN: 2226-6348 @ 2021 HRMARS

\section{References}

Ahmad. L. H. (2014). Persepsi Pelajar terhadap kurikulum Pendidikan Islam Politeknik dalam Pembentukan sahsiah Muslim. Jurnal Pendidikan Malaysia 39(2): 133-140.

Alessi, S. M., \& Trollip, S. R. (1991). Computer Base Instructional: Metods and development. Ed. Ke-2. New Jersey: Prentice Hall

Awang, A. (2011). Penghayatan ibadah dan kesannya terhadap hubungan sosial di kalangan pelajar Sekolah Menengah Kebangsaan Agama Tok Jiring, Kuala Terengganu / Aerisuli binti Awang. Masters thesis, University of Malaya.

Bunt, G. R. (2010). Surfing the App Souq: Islamic Applications for Mobile Device. Journal of the Virtual Middle East. 4.

Chung, K. H., \& Shin, J. I. (2010). The antecedents and consequents of relationship quality in Internet shopping. Asia Pacific Journal of Marketing and Logistics, 22 (4), 473-491.

Haron, D., \& Salamon, S. (1988). Masalah Pendidikan di Malaysia. Kuala Lumpur: Al-Rahmaniah Badan Dakwah dan Kebajikan Islam Malaysia.

Individuals with Disability Education Act Amendments of 1997 (IDEA). Public Law 105-17-June 4,1997 1 Public Law 105-17-105 th Congress Senate and House of Representatives of the United States of America in Congress assembled.

Islam, M. R., Mazumder, M.R. \& Arafhin, T. (2010). Mobile Application and Its Global Impact. International Journal of Engineering \& Technology IJET-IJENS, 10 (6), 72-78.

Ismail, R., Samsudin, S. N., Sulaiman, A. W., Zainol, N., \& Zaid, D. S. (2016). Kajian Literatur Terhadap Aplikasi Mudah Alih Berunsurkan Islam (Literature Review On The Islamic Mobile Apps). Journal of Global and Sosial Entrepreneurship (BGSE) Vol.: no.5 (2016) page174-182. elSSN 24621714.

Johari, N. S., Fakhruddin, F. M., \& Suhid, A. (2016). Pendekatan Dan Kaedah Pengajaran Ibadah Solat Guru Pendidikan Islam Menurut Perspektif Murid. Online Journal of Islamic Education (O-jiE). Vol 4 No 2: 46-53.

Kaminski, K., Switzer, J., \& Gloeckner, G. (2009). Computers and Education Workforce readiness: A study of university students' fluency with information technology. Computer and Education Journal. Volume 53, Issue 2 Pages 201-540.

Khairuldin, W. M. K. F. W., \& Mohammad, M. (2013). The Philosophy and Elasticity of Zakah Distribution in Islam. International Journal of Education and Research Vol. 1 No. 8 August 2013.pages 1-12.

Mamat, N., Mustafa, M. C., Razalli, A. R., Hashim, A. M. M., Hamdan, A. H., \& Asong, R. (2020). Use of Interactive Media to Improve Understanding of English Language for Children. International Journal of Academic Research in Business and Social Sciences, 10(12), 613620.

Mukti, N. A. (2000). Computer Technology In Malaysia: Teachers' Background Characteristics, Attitudes and Concern. Atas talian www.ejisdc.org/ojs2/index.php/ejisdc/article/view/20/20

Miswan, M., \& Adnan, H. M. (2015). Pembangunan Aplikasi Peranti Mudah Alih Untuk Kemahiran Membaca Kanak-Kanak: Aplikasi Literasi Linus (Lilin), Jld, 17, Bil 2, 64-75 
Nawi, A., \& Hamzah, M. I. (2013). Tahap penerimaan penggunaan telefon bimbit sebagai Mpembelajaran dalam Pendidikan Islam. JIAE: Journal of Islamic and Arabic Education, 5 (1). pp. 1-10. ISSN 1985-6236

Razalli, A. R., Ibrahim, H., Selamat, S., Salleh, N., \& Abdullah, M. A. (2015). Penggunaan Model Pengajaran Berasaskan Bahasa Isyarat (MOPBIS) dalam Pengajaran Bahasa Melayu Murid Pekak. The Asean Journal of Knowledge Contribution. Volume 3, pg 53-60.

Sahir, S. (2011). Penggunaan ICT dalam Kalangan Guru Pemulihan Sekolah Rendah dalam Daerah Hulu Selangor. Kertas projek belum diterbitkan, Universiti Pendidikan Sultan Idris

Salleh, A. M. (2004), Pendidikan Islam: Falsafah Sejarah dan Kaedah Pengajaran Pembelajaran. Shah Alam: Penerbit Fajar Bakti Sdn. Bhd

Sidek, S. F., Fathil, N. S., Zain, N. Z. M., \& Muhammad, K. (2014). Pembangunan Perisian Kursus 'Saya Suka Belajar' Untuk Pembelajaran Bahasa Melayu Bagi Kanak-kanak Autisme. Malay Language Education Journal. Fakulti Pendidikan, Universiti Kebangsaan Malaysia. 4 (1). pp. 1-10. ISSN 2180-4842.

Siwok, S. R., Ghani, F. A., \& Omar, A. H. (2018). Instruments Used in Exploring the Experience of Parents of Children with Hearing Losses. In the International Conference on Social Science \& Humanities 2018 proceeding. Johor Bahru: Universiti Teknologi Malaysia.

Siwok, S. R. (2016). A Framework for Helping Muslim Parents of Children with Hearing Loss in a Special Education School in Malaysia. Unpublished Phd Thesis. Universiti Teknologi Malaysia.

Tariq, U. U., Wu, H., \& Ishak, S. A. (2020). Energy and memory-aware software pipelining streaming applications on NoC-based MPSoCs.Future Generation computers system. Volume 111, October 2020.pages 1-16.

Vázquez-Cano, E., León-Urrutia, M., Parra-González, M. E., \& López Meneses, E. (2020) Analysis of Interpersonal. Competences in the Use of ICT in the Spanish University Context. Sustainability 2020, 12, 476.

Wyche, S. P., Caine, K. E., Davidson, B., Arteaga, M., Grinter, R. E. (2008). Sun Dial: Exploring Techno-Spiritual Design through a Mobile Islamic Call to Prayer Application. In CHI 2008 Proceedings, pp. 3411-3416. Florence, Italy

Wyche, S. P., Caine, K. E., Davidson, B., Arteaga, M., \& Grinter, R. E. (2008). Sun Dial: Exploring Techno-Spiritual Design through a Mobile Islamic Call to Prayer Application. In CHI 2008 Proceedings, pp. 3411-3416. Florence, Italy.

Yin-Fah, B. C., Lay-Yee, K. L., \& Kok-Siew, H. (2013). Factors Affecting Smartphone Purchase Decision Among Malaysian Generation Y. International Journal of Asian Social Science ISSN(e): 2224-4441/ISSN(p): 2226-5139

Yusuf, Y. (2006). Keberkesanan Kurikulum Pendidikan Islam Sekolah Menengah Dalam Pembentukan Akhlak Pelajar. Disertasi ljazah Sarjana Syari'ah. Univerisiti Malaya, Kuala Lumpur.

Zaffwan, M., Yusoff, S., \& Hoe, T. W. (2013). Permainan Digital: Pendekatan Baharu Dalam Pendidikan Masa Depan. Prosiding Seminar Kebangsaan ICT dalam Pendidikan

Zeki, A. M., Alsafi, H., Nassr, R. M., Mantoro, T. (2012). A mobile dictionary for pilgrims. In Information Technology and e-services (ICITes), pp.1-5. International Conference on IEEE. 